\title{
Strategic Management as a key for Superior Competitive advantage of Sanitary Ware Suppliers in Kingdom of Saudi Arabia
}

\author{
Baha`a Abdul-Hafez Attallah Al-Nady ${ }^{1}$, Sulieman Ibraheem Shelash Al-Hawary², \\ Main Naser Alolayyan ${ }^{3}$ \\ ${ }^{1}$ Business Coach and Researcher, Master in E-Business, Faculty of Business, \\ Middle East University, P.O.Box 230505 Amman 11123 Jordan. bahadh@hotmail.com \\ ${ }^{2}$ Associate Professor of Business Management, Department of Marketing, Faculty of Business and \\ Finance, American University of Madaba, P.O.BOX 2882, Amman 11821, Jordan \\ dr sliman73@aabu.edu.jo, dr sliman@yahoo.com \\ ${ }^{3}$ Business Administration Department, Al-khawarizmi University Collage, \\ United Arab Emirate, Abu-Dhabi, P.O. Box 25669 \\ Dr.alolayyan@rocketmail.com
}

\begin{abstract}
Strategic Management has become an essential nowadays as managerial techniques have been developed and used successfully by many of professional business corporation such as General electric and the Boston Consulting Group. Initially strategic Management was of most use to professional corporations operating in multiple industries. Increasing risk of error, costly mistakes, misunderstanding market needed and even economic ruin are causing today's professional managers in all organizations to take Strategic Management seriously in order to keep their companies competitive in an increasingly volatile environment. In this study we will focus on Suppliers who deal with sanitary ware (Bathroom accessories, Mixers, Bathtub) in Makkah and Jeddah Cities, Kingdom of Saudi Arabia. Mostly people in Makkah and Jeddah Cities prefer to purchase from various outlets vendors / retailers who are available usually in same area, according to their convenience, preference and selection. Increases in expectations and changing culinary style of consumers make the Sanitary Ware (Bathroom accessories, Mixers, Bathtub) business dynamic in general. Despite the increasing interest in the area there are very little researches on Superior Competitive Advantage of sanitary ware vending service in our domestic market. Keeping these conditions in view, this study tries to explore the current scenario in which Sanitary Ware (Bathroom accessories, Mixers, Bathtub) has become a flourishing business for a lot of Suppliers as it has been successful in attracting a large mass of customers and projects. This study analyses Strategic Management as the key for Superior Competitive Advantage of Sanitary Ware (Bathroom accessories, Mixers, Bathtub) in Makkah and Jeddah Cities.

The present survey has been done with 112 retailers who purchase sanitary ware from sanitary ware suppliers companies in Makkah and Jeddah Cities. It identifies the most relevant understanding of Strategic Management as the key for Superior Competitive Advantage, and determines their influence in choosing of Sanitary Ware outlets. The results show that Strategic Management as independent variable has a positive influence on Superior Competitive Advantage of Sanitary ware suppliers in Makkah and Jeddah Cities.
\end{abstract}

Keywords: Strategic Management, Superior Competitive Advantage, Sanitary Ware Suppliers, Kingdom of Saudi Arabia.

\section{Council for Innovative Research}

Peer Review Research Publishing System

Journal: International Journal of Management \& Information Technology

\author{
Vol. 7, No. 2 \\ editor@cirworld.com \\ www.cirworld.com, member.cirworld.com
}




\section{INTRODUCTION}

Strategic Management is a set of managerial decision and actions that determines long-run performance of corporation; it includes environmental scanning, strategy formulation, strategy implementation, evaluation / control, and feedback / learning (Wheelen et al. 1981). Strategy has been at the top of the CEO's agenda for many years, Strategy is all about action, it can be drawn as a map that shows how activities support each other and together how they contribute towards strategic goals. Recently, the strategy that leads organization is not traditional strategies such as product development and services, homogenous variety, Business areas and services development, cost reduction and assignment, but also Innovations value making as a strategy that adopting it has reduced costs and the same time caused more value to the Organization stakeholders (Bagheri Rouhollah et al. 2013). Value innovation is about the strategies which embrace all the activities in the system (Porter, E. Michael, 1996). Organizations need to think about the issue beyond the competition to capture new growth opportunities and profitability (Debi S. Saini, 2006). Strategy is claims that a proper link between strategy and manufacturing operations, it is a key to developing sustainable competitive advantage (Porter, M.E., 1996). Strategic management has become a key of superior competitive advantage in the global marketplace, both domestically and internationally, it can affect many number of business units and it is a key element of successful oversea organizations.

Strategic practices will capitalize those strengths in order to grab available opportunity and at the same time address weakness and minimize threats from external environmental factors including competitors (Yaacob and Ju, 2013). The initial dimension of strategic management is environmental scanning by gathering information about market (customers, retailers, suppliers) and to know external opportunities and threats as well as internal strengths and weakness of organization. During environmental scanning professional manager of sanitary ware suppliers will try to know about customer expectation, sanitary ware retailers preference and sanitary ware competitors for which type of sanitary ware products they supply the market, therefore environmental scanning consider as first important dimension of strategic management for any type of business as it helps to establish correctly business and boost the business of organization. The others dimensions of strategic management are strategy formulation, strategy implementation, evaluation / control and end with feedback / learning. Based on our domain knowledge and experience, we would like to state that, Strategic Management is now an increasingly common management practice. When using this approach it is important to keep abreast of our market for new and upcoming players who through some variable, whether it be new technology or an aggressive advertising campaign, may become a dominant player. Any business environment a product similar to, or as a substitute for, our own sanitary ware product in the same geographic area is a direct competitor. Firms offering dissimilar or substitute products in relation to our product or service are considered indirect competitors. Indirect competition would exist between the manufacturer of tiles such as ceramic and porcelain and a manufacturer of Marbles and granite selling to the same customers. Another example is the manufacturer of eyeglasses who competes indirectly with contact lens manufacturers. Stated in other terms, indirect competition will satisfy the customer's need with a particular product or service. Today's market calls for Strategic Management, characterized by high quality, functionality to stand out from the crowd competitions. The Sanitary ware suppliers have a direct contact with the customer. So it is imperative to work closely to know about what a customer need as customer the key role in any business, without customers a business cannot exist. The customer consider as key player in Competitive advantage of sanitary ware vendors, So the customer is the major part of a business and a business succeeds only because of the customer, without the customer there is no business (Rehman et. al.,2013).

At present, in Saudi Arabia housing demand is rapidly rising and with increasing purchasing power people have started taking interest in premium sanitary ware products. Sanitary ware demand comes from new projects as well as from replacement market. In Makkah and Jeddah cities would also soon become a hub for international sanitary ware brands. International brands such as (Roca, Grohe, Hansgrohe, Fiore, Elallar, Geberit, Nobili, Wisemaker, SSWW, Potter, and Sannora) year by year plan to expand their scale of operations in Saudi Arabia Market. The expansion for international brand will be either through Brownfield expansion of their joint venture partners or through setting up Greenfield ventures. These companies will cater to the rising consumer demand within Saudi Arabia for branded and premium sanitary ware products. Saudi Arabia booming Contracting industry and growing upscale consumer market present a big opportunity for international brands. The competition between Sanitary ware Suppliers encourage them to distribution many Sanitary ware products in Makkah and Jeddah Cities of Saudi Arabia and that create competition between Sanitary ware (Bathroom accessories, Mixers, Bathtub - see Appendix 1,2) Suppliers then problems appear towards increasing risk of error, costly mistakes, misunderstanding Sanitary ware product types and market needed without concern on Strategic Management and that cause to high failure rates of Competitive advantage. Hence, the researcher finds that there is need to understand role of Strategic Management as the key for Superior Competitive Advantage. Therefore it has been a considerable interest in methods and concepts for studying role of Strategic Management as the key for Superior Competitive advantage of sanitary ware (Bathroom accessories, Mixers, Bathtub) suppliers in Makkah and Jeddah cities (Alnady,May.2012).

\section{REVIEW OF LITERATURE}

\subsection{Strategic Management (SM)}

Strategic management provides the route map for the firm. It lends a framework, which can ensure that decisions concerning the future are taken in a systematic and purposeful way (Thenmozhi, 2011). Strategic management is a set of managerial decisions and action that determines the way for long-range performance of the company; it includes environmental scanning, strategy formulation, strategy implementation, evaluation /control and feedback/learning (figure 
1.2). (Wheelen et. al. 1981) suggested Strategic Management concept in firms business which start with environmental scanning by collect and analyze information since it consider as first important dimension of strategic management then follow it strategic formulation as second dimension which included reason of existence, objectives, strategic plan, broad guideline, then strategic implementation as third dimension which suppliers / retailers make a purchase decision based on their programs, market needs, budget limitations, and other constraints impinging on them, then control / evaluate as fourth dimension which supplier improved its ability to innovate, rapidly commercialize and responsive to new sanitary ware market change and end with feedback learning fifth dimension. Which firm focuses on creating differentiated products, technological leadership and higher return on investment (Wu and Lin, 2009). As more industries become global, strategic management is becoming an increasingly important way to keep track of international developments and position a company for long term competitive advantage (Wheelen et. al. 2006).

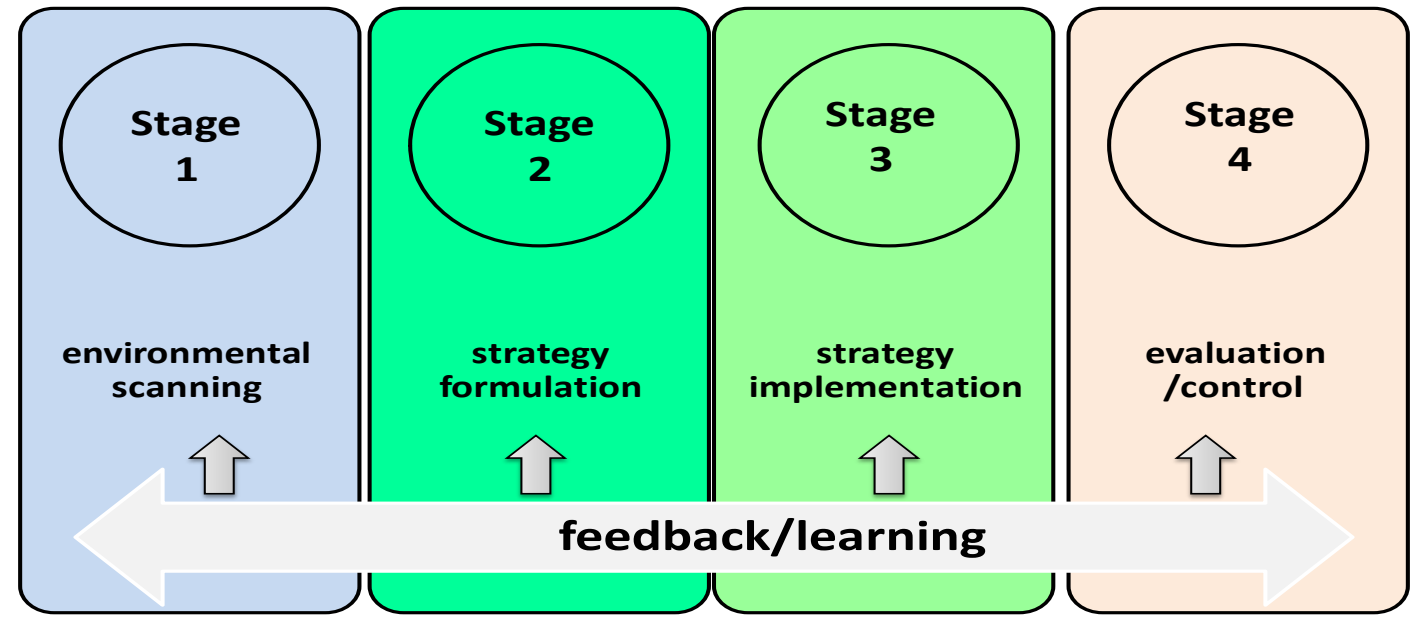

Figure 1.2, describe Strategic Management main stages, compiled by Bahaa Alnady,2013

\subsubsection{Environmental Scanning}

Environmental scanning can be defined as 'the study and interpretation of the political, economic, social and technological events and trends which influence a business, an industry or even a total market (Kroon, 1995). It emphasizes the monitoring and evaluation of external opportunities and threats in light of corporation's strength and weakness. (Turban et al, 2006) believe that with respect to this terms, it's not enough just to gather information on a competitor, Analyzing and interpreting the information is as important as collecting it. (Wheelen\& Hunger, 2006) defined environmental scanning as it is the monitoring, evaluating and disseminating of information from external and internal environments to key people within the corporation and both internal and external elements will determine the future of the corporation. The researchers defined Environmental Scanning as it requires an analysis of what is happening in external environment (which includes industry forces and general forces) and internal environment (which includes forces such as the corporate culture, structure and resources) and an evaluation of current resources (strength and weakness) and an assessment of (opportunities and threats) present in the environment as described in (figure 1.3). In any business environment SWOT analysis can help gauge the strengths, eliminate weaknesses, and exploit opportunities in a given market and avoid or deduce threats from competitors. The key benefits of a properly conducted environmental scanning are save time and efforts in generating leads, make profitable deals with more suitable distributors, reduce our time to market, not waste cash on ineffective campaigns. There are several specific areas that should be considered, including the overall environment, the specific industry forces and general forces in external environment, and the corporate forces in internal environment of the firm. The resulting consequence of regular inspection of the overall environment is that an organization readily notes changes and is able to adapt its strategy accordingly. Refer to (figure 1.3). External environment forces divided to (I) Industry forces such as (customers, suppliers, competitors, shareholder, government, and communities) and (II) General forces such as (socio cultural, educational, economic, technological, geographic, political and legal) additional to all these forces external environment consists of variables (opportunities and threats) that are outside organization and not within short-run control of top management. From other side, looking internally, there are several key areas that must be analyzed and addressed; this includes identifying the status of each existing line of business and unused resources. Internal environment forces divided to (1) Corporation culture (beliefs, expectations, and values), (2) Corporation structure (chain of command) and (3) Corporation resources (labors own "qualifications, experience, competencies, skills \& knowledge", Assets such as "capital, tools, equipments, goods \& properties") additional to all these forces internal environment consist of variables (strengths and Weaknesses) that are within the organization itself. People in an organization can use their competence to create value in mainly two directions: externally or internally, if managers of car or Soap Company direct the efforts of their people internally, they may create tangible structures such as machinery and tools and intangible structures such as better processes and new designs for products (Sveiby karl-erik, 2001). 


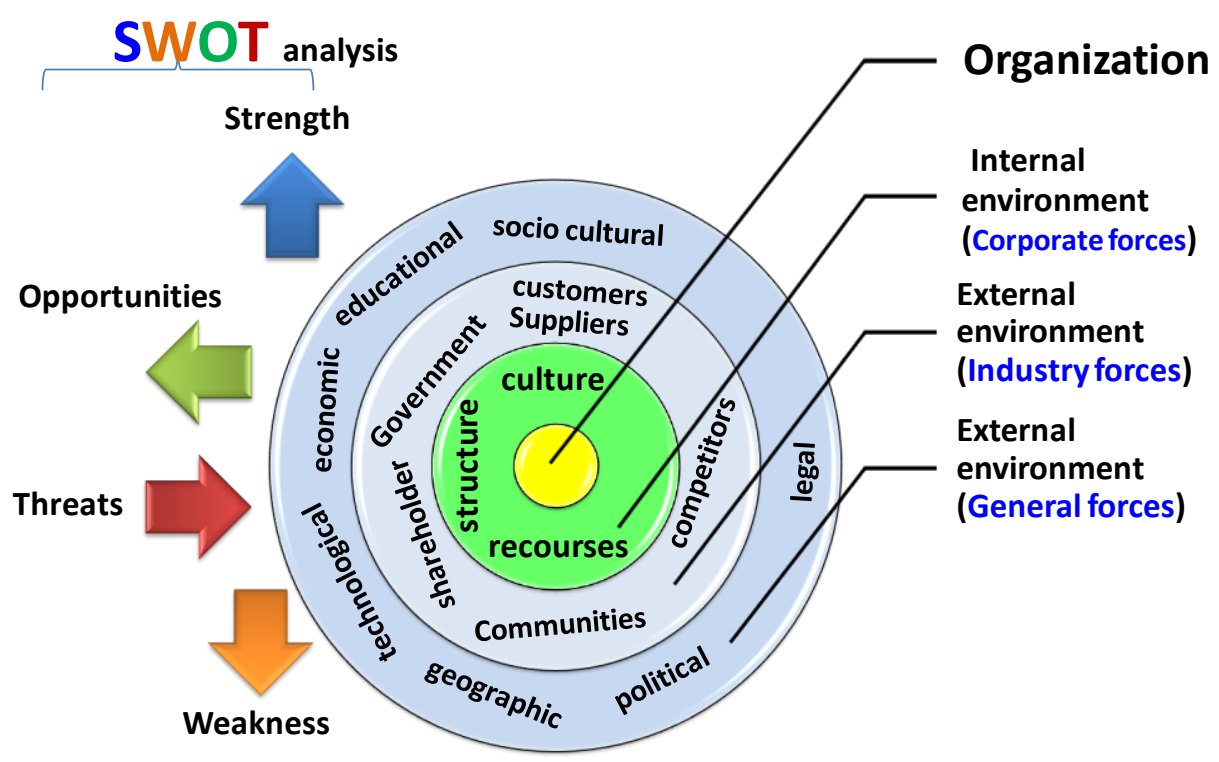

Figure 1.3, describe environmental scanning forces, compiled by Bahaa Alnady,2013

\subsubsection{Strategy Formulation}

Strategy formulation allows a company to position itself effectively and efficiently within its environment (internally and externally) to reach its maximum potential, it give us idea about current situation, and where we are going, and how we are going to get there. It is the development of long range plans for the effective management of environmental opportunities and threats in light of corporate strengths and weaknesses. It includes defining the corporate mission, specifying achievable objectives, developing strategies and setting policy guidelines (Thenmozhi, 2011). Strategies formulation is one of most important task of enterprise management as it enables business operations to be steered in the right direction. The competitive analysis of the external and internal environment plays a necessary role in establishing the conditions for strategies formulation (Pearce, J.A. et al. 2005). Strategy formulation is the development of long-range plans for the effective management of environmental opportunities and threats in the light of corporate strengths and weaknesses (Wheelen\& Hunger, 2006). To be successful in this globally competitive, rapidly changing environment, organizations must formulate strategic plans that are consistent with their investment in and use of manufacturing technology (Tracey Michael, 1999).

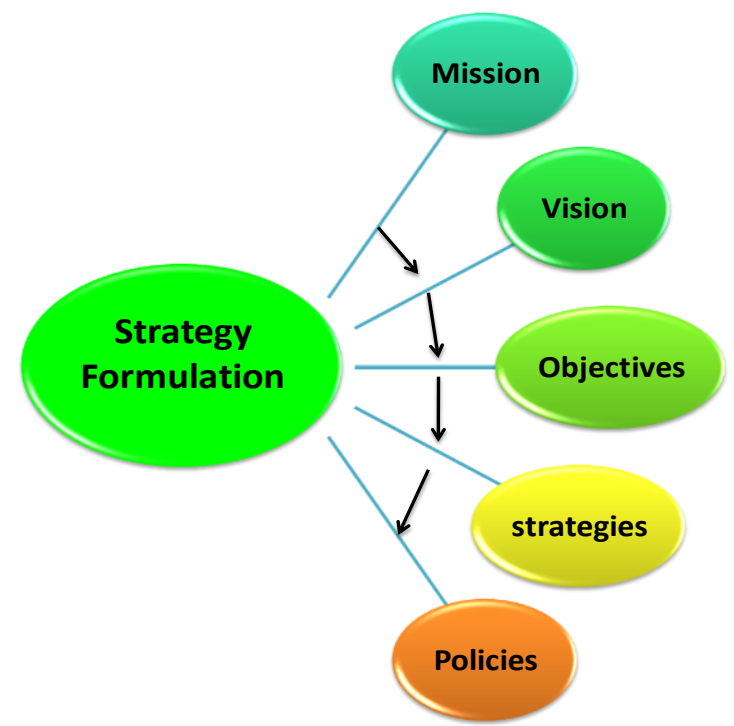

Figure 1.4, describe Strategy Formulation stages, compiled by Bahaa Alnady,2013

To successfully implement advanced technology, an organization must allow manufacturing's evolving competencies to be a driving force in strategy formulation (Harrison, 1990; Parthasarthy and Sethi, 1992; Ettlie and Penner-Hahn, 1994). 
Porter (1996) describes the relationship between strategy and operational effectiveness as fundamental to competitive advantage and even more important to sustain that advantage. Strategy formulation should start with the competence of people who are seen as the only true agents in business; all tangible physical products, assets as well as the intangible relations are results of human action and depend ultimately on people for their continued existence (Sveibykarl-erik, 2001). Refer to above (figure 1.4) strategy formulation included corporate mission, vision, objective, strategies, and policies. (First stage); Mission which is the purpose or reason for the organization existence, it statement describes what the organization is now. Generally formulating a mission statement, it should included six specific elements; start with basic product or service, employee orientation, primary market(s), customer orientation, principle technologies, and standards of quality. With all of these elements incorporated, a mission statement should still remain short and memorable. For example, the mission statement of the American Red Cross, reads: "The mission of the American Red Cross is to improve the quality of human life; to enhance self-reliance and concern for others; and to help people avoid, prepare for, and cope with emergencies." (Second stage); Vision which statement describes what organization would like to become. A vision is identifies where an organization wants to be at some point in the future, it functions to provide a company with directionality. (Third stage); Objectives which are the end results of planned activity, what is to be accomplished, what are the goals of the organization?. If the goal is to be profitable, then how much profit?. (Forth stage); Strategies which are plans that state how the corporation will achieve its mission and objectives, what direction should the organization take to achieve its objectives? Is it by 'building strong supplier relationships or customer relationships' or by 'expanding into new markets', usually firms consider three types of strategy: corporate, business and functional. Corporate strategy fit within three categories of stability, growth and retrenchment. Business strategy grouped into two categories: competitive and cooperative. Functional strategy is approach to achieve corporate and business unit objectives by maximizing resource productivity and provide a company with a competitive advantage. And the final (Fifth stage); are Policies which are a broad guidelines for decision making that links the formulation of strategy with the implementation strategy.

\subsubsection{Strategy Implementation}

It is the process by which strategies and policies are put in to action through the development of programs. This might involve changes within the overall culture, structure and/ or management system of the entire organization. Strategies are implemented through a set of programs, budgets and procedures (Thenmozhi, 2011). Strategy implementation is a process by which strategies and policies are put into action through the development of programs, budgets and procedures (Wheelen\& Hunger, 2006). Implementation of the strategic is the final step for putting it to work for an organization. To be successful, the strategy implementation must have the support of every member of the firm; this is why the top management must be involved from the beginning. A company's leader such as Management director or CEO is its most influential member. From other side the more often employees hear about the implementation strategy plans, the greater the possibility that they will undertake it as part of their daily work lives.

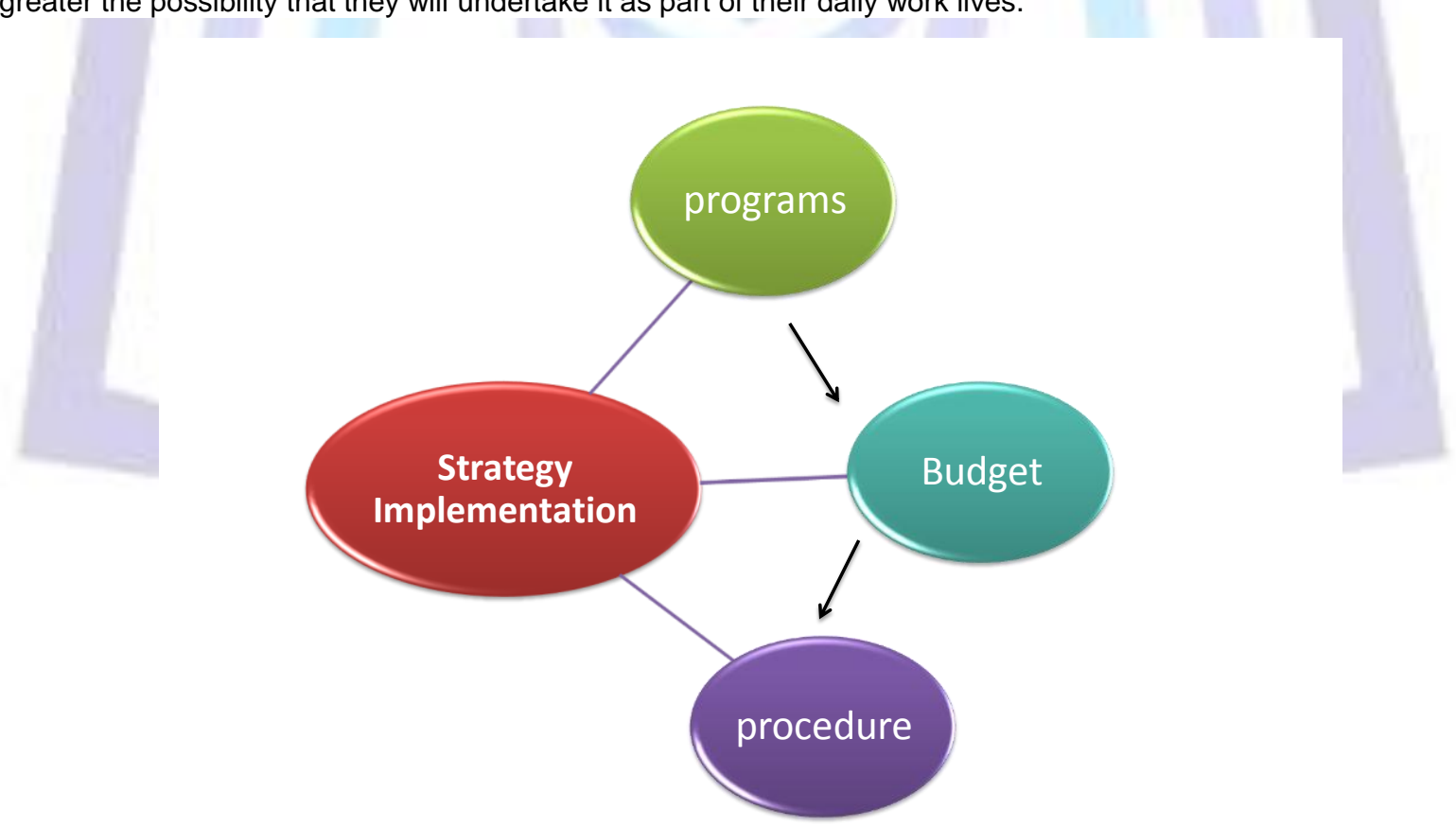

Figure 1.5, describe Strategy Implementation stages, compiled by Bahaa Alnady, 2013

The essence of strategy implementation is to properly position the products, services, information and develop programs that can be executed by addresses issues such as setting a price for a product, determining the structure of a distribution network, defining product specifications, target customers, market segmentation, put set of business plans such as forecasting sales, procurement plan, marketing plan, finance plan. The key benefits of a properly strategy implementation are reduce sales cycles because products are properly positioned via forecasting sales plan, know where to find our key accounts for large and repeating sales via market segmentation, acceptance price for largely customers, prepare right 
budgets in the most efficient way via finance plan since we only develop products that meet a real demand via procurement plan. Strategy implementation requires people to take responsibility to do the right things and it requires performance to be analyzed in terms of what things are working, which things are not, and what changes to both activities. Strategy implementation can be defined shortly as putting strategies into action through creating right programs, budgets, and procedure. (1) Programs are steps needed to accomplish a single plan. (2) Budgets are a corporation programs in terms of dollars, its included list and details cost of each program. (3) Procedures are techniques describe how a particular task or job is to be done. This naturally dictates that all implementation cannot be postponed until completion of the steps, but must be initiated along the way. Implementation procedures specific to each step must be completed during that step in order for the next stage to be started.

\subsubsection{Evaluation and Control}

It is the process in which corporate activities and performance can be compared with desired performance, Based on the performance results, management may need to make adjustments in its strategy formulation or implementation or both (Thenmozhi, 2011). Simply, evaluation and control can be defined as process that ensures that the company is achieving what it set out to accomplish and compares performance with desired results. Evaluate current performance results in terms of return on investment, Profitability in the light of current mission, objectives and policies. Performance is the end result of activities; it included outcomes of the strategic management process. There are two simple questions to answer: "What are we doing now that we need to stop doing?" and "What do we need to do that we are not doing?" Employees who are very knowledgeable about the product will be much more valuable, and a willingness to figure out answers to difficult questions will keep the specialty "power user" coming back. The wrong person in the wrong store will be a disaster in either case.(Swamidass and Newell, 1987) surveyed 35 firms from the Pacific Northwest. They found that firms with high levels of manufacturing manager's participation in strategic decision-making had higher performance as measured by growth in sales, return on total assets, and return on sales. (Ward et al., 1994) examined 60 firms across five industries all operating in the state of Ohio. The study showed that firms with high levels of manufacturing manager's involvement in strategy development, investment in specific manufacturing capabilities, and worker participation also had high performance as measured by market share and sales. Evaluation and control transmits the signals from top management to the rest of the organization in a form that can bring about change at every level.

\subsubsection{Feedback / learning}

Feedback is widely used in coaching practice where it is provided to support self-awareness, learning, and to improve performance. (Jarzebowski et al., 2012). It is information regarding individuals' current levels of performance, has been shown to influence motivation, job satisfaction and performance (DeNisi \& Kluger, 2000; Gregory, Levy \& Jeffers, 2008). Feedback is a general term used to describe the information a learner receives about the performance of a movement or skill (Kirazci Sadettin, 2013). That information can be available from both internal and external sources (Coker, 2004).

Feedback/ learning process is often must go back to revise or correct decisions made earlier in the process for example poor performance usually indicates that something has gone wrong with either strategy formulation or implementation strategy or a new competitor was ignored during environmental scanning (Wheelen\& Hunger, 2006). The researchers found that, feedback / learning refers to the sum total of information's, experiences, experimentation which coming from environmental scanning, formulation strategy, implementation strategy, and evaluation. Recently, feedback or Organizational learning is increasingly being considered as one of the fundamental sources of competitive advantage within the context of strategic management (Njuguna, 2009). Accordingly, in prevention focus, success is represented as the absence of a negative outcome (not missing a goal) while failure is represented as presence of a negative outcome (missing a goal). Consequently, adhering to negative feedback supports the avoidance of failure (the undesired state in prevention focus), whilst adhering to positive feedback supports the achievement of goals (the desired state in promotion focus) (Jarzebowski et al., 2012). (Yeung et al., 1999) suggested that the firms must determine their knowledge strategy based on whether their efforts are best focused on learning methods from direct experience or the experience of others and learning orientation of exploration or exploitation. This was also emphasized by (Goh, 2003) who noted that to remain competitive; many organizations are adopting a strategy of continuous learning. They encourage employees to learn new skills continually to be innovative and to try new processes and work methods in order to achieve the strategic business objectives of the organization. Particularly in the beginning of the career, positive feedback strengthens self confidence and one's trust in his/her abilities, Positive feedback also makes it possible to work towards the right goals and supports the development of the employee by highlighting good working methods, work gives positive feedback to the employee when the work is experienced as being well done (Koskiniemi and Perttula, 2013). At work (internal environment); one is hard working and motivated in spite of the received positive feedback, when new employee start working in any work atmosphere for sure he will face many challenges because the employees create their work atmosphere, therefore the quick adaptive of new employee at work atmosphere is consider positive feedback, when the new employee receives positive feedback it is always jointly deserved among other employees. From other side in work (external environment); when employee gets positive feedback from clients because of positive interact between client and employee and paying attention to clients' needs, an employee can expect reciprocal consideration from clients. Receiving positive feedback is experienced when one employee work hardly to compete his colleague and success to make excellent business deal with clients and bring high income for his organization. At end always work gives positive feedback when the employee (worker) is pleased with the work atmosphere. One thing very important, before we ask about feedback in work environment, we have to identify work atmosphere is it healthy or not, does the current employees success people or need training, does they have the right qualifications, and meet business requirements or not, because sometimes same work atmosphere not healthy therefore we can't get positive feedback unless we do some or complete change, for example FGC one of construction company at Saudi Arabia who have unhealthy work atmosphere due to hiring and selecting employees with low salaries in order to save expenses, and logically those employees come with low qualifications and 
low skills who create many mistakes in work and transfer negative attitude and do badly reaction with work environment internally and externally, therefore what does FGC owner expect to happened, what feedback he will get?. Frankly researcher found that, FGC one of the companies who loss many projects due to negative feedback, one of these project was contract worth 45 million signed two years ago with government to build 500 apartments, but unfortunately it cancel due to unhealthy work atmosphere which create problems inside project, negative feedback and delay deadline of projects till reach to closed road and government cancel the contract at end. Furthermore, the researcher noted that, many of business owners do same mistake every time such as hiring professional senior employee to improve the business then success the company without give attention to work atmosphere, since if work atmosphere not healthy the result will be negative feedback even if we hire pro- senior employee, and the only solution is to clean work atmosphere from negative unqualified employees to give ability to pro- senior employee to success and get positive feedback at overall. Positive feedback is important in spite of who gives it, the credibility of positive feedback grows when it is received face to face, when work is done for the clients, positive feedback from them is deemed valuable, Positive feedback energizes the worker, reinforces one's own image as an important employee and positively affects well being at work (Koskiniemi and Perttula, 2013).

Success depends on close and careful linkages between a firm's manufacturing strategies and its overall strategy, these linkages help to guide decisions about how manufacturing technologies are applied, which competitive capabilities are achieved and, ultimately, how well firms perform (Skinner, 1969; Porter, 1996). The design of manufacturing systems should focus on developing competitive capabilities that satisfy customer needs and improve performance (Ward et al., 1994). To cope with the changing environment, customer needs, and competitive factors, organizations should develop policies and practices that enable manufacturing managers to participate in strategy formulation and allow these linkages to guide their investments in and use of manufacturing technologies (Tracey Michael, 1999). Success strategy will reflect the organization's goals, values, recognize its strengths and weaknesses compared to the competition, if those goals are not achieved or the strategy fails, then the person ultimately responsible is the CEO.

The fact is most CEO and managers are now required to be more successful with fewer resources. So, technically, all $\mathrm{CEO}$ and managers are strategists. The reality, however, is that not all managers are good strategists. Herein lies the pearl of great opportunity: the deeper manager can dive into the business and resurface with strategic insights, the more valuable manager will become to your organization, but how to build and improve the organization competitive position for each of its lines of business. The researchers emphasize that, organization has competitive advantage whenever it can attract right customers, right suppliers and defend against competitive forces better than its rivals. Organization own superior competitive advantage whenever apply strategic management, below (figure 1.6) is summarize all stages of strategic management.

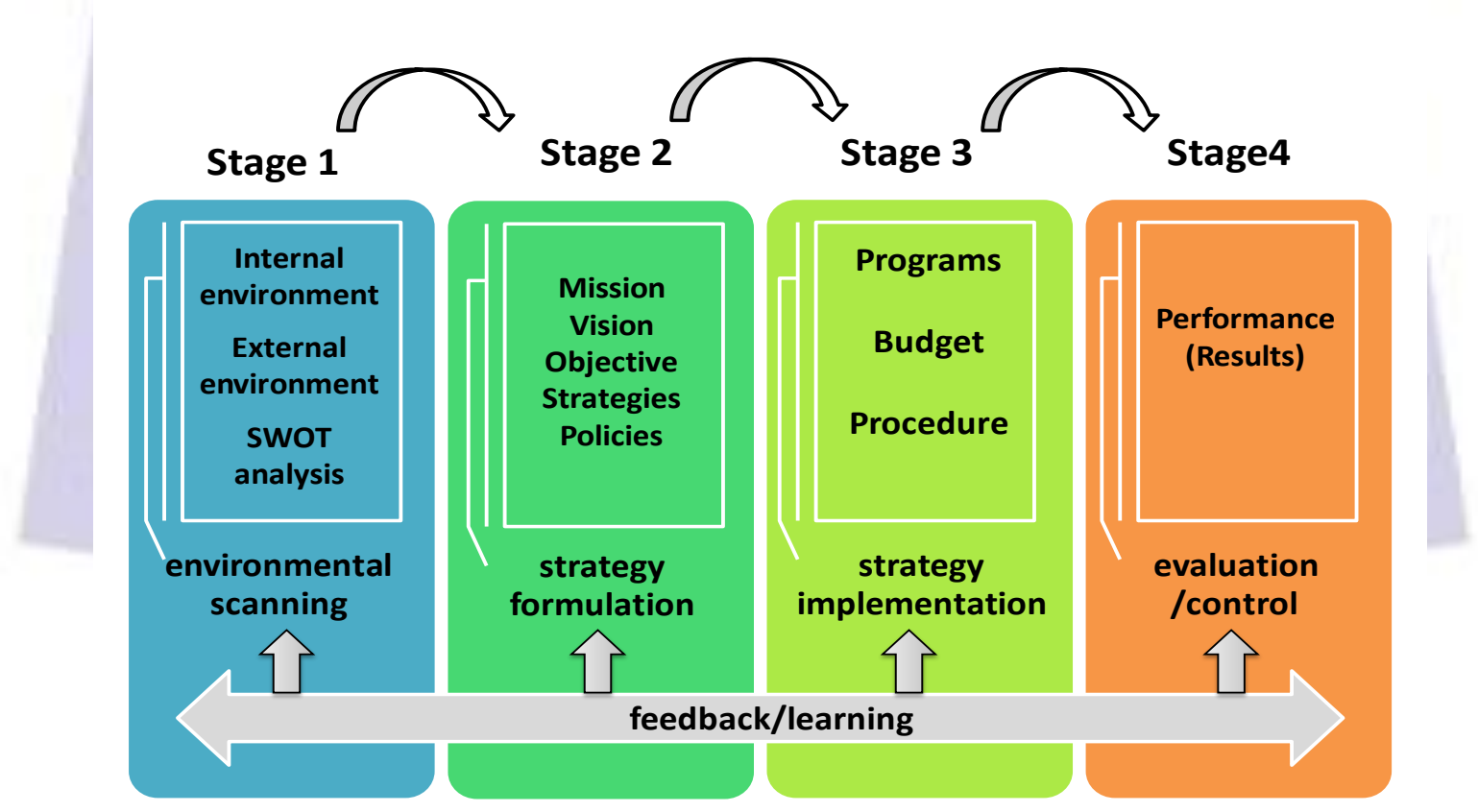

Figure 1.6, describe Strategic Management all stages, compiled by Bahaa Alnady,2013

\subsection{Superior Competitive Advantage (SCA)}

Wal-Mart's superior profitability reflects a competitive advantage that is based on the successful implementation of a number of strategies. These strategies resulted in higher productivity and lower costs than rivals, which enabled the company to earn a high profit while charging low prices. TNT's and DHL's history provides excellent examples where the manage processes successfully maintained a winning formula and developed this formula to create further competitive advantage, both of these enterprises started with providing a reliable parcel delivery service. However, here it is clear that, the management teams in these organizations, having recognized a winning formula successfully developed this formula to sustain and develop their competitive advantage (Bititci et. al., 2003). The competitive advantages/ disadvantages 
analyzed from the internal and external competitive environment, such as strength, weakness, opportunities and threats in SWOT analysis, provide important and specific messages to position industrial development trends and formulate the development strategies (Grant, R. M. 2008). Therefore, achieving a competitive advantage is a major pre-occupation of senior managers in the competitive and slow growth markets, which characterize many businesses today and the sources of competitive advantage have been a major concern for scholars and practitioners for the last two decades (Henderson, 1983; Porter, 1985; Coyne, 1986; Prahalad and Hamel, 1990; Barney, 1991; Grant, 1991; Peteraf, 1993). Thus, it is understood that across sectors most firms should recognize that attaining competitive advantages is the most challenging issue facing firms for centuries. This concern has lead to the development of resource-based and knowledge-based theories that examine the relationship between core resources and capabilities; sustainable competitive advantage and above normal performance. According to porter (1985) the principal types of competitive advantage are low cost producer, differentiation, and focus. The firm has a competitive advantage if it is able to deliver its product or service at a lower cost than its competitors. If the quality of its product is satisfactory, this will translate into higher margins and higher returns.

Generally any market driven by global competition and slow-growth economies and industries, many organizations search for new ways to achieve and retain a competitive advantage (Sunhilde,2011). A competitive advantage could basically be defined as the advantage or ability a firm has over its rivals because the company wants the gap between perceived value and cost of the product to be greater than the competition (Porter, M. (1980). Knowledge resource is unique and valuable for a link to competitive advantage, Knowledge is critical to the capabilities of effective organizational learning (Wu and Lin, 2009). Good segmentation of the market and hence a better knowledge of customers is key to increasing competitiveness (Banabakova and Stoyanov, 2009). Managers, on one side, understand that the only competitive advantage that the future firm will have lies in its ability to learn faster than its competitors (DeGeus, 1988; Hansen,2002). Competitive advantage creation must be a choice of management and it must really fit to achieve results (Pressman and Steven,1991). Many companies have built sustainable and superior competitive advantage through their choice of right human recourse people who have the ability to select right sales team and right distribution team. Over the years, business models have become much more sophisticated therefore selecting sales and distribution approach has become a key element of a successful business model (Sunhilde, 2011). In addition many business people consider customer service as central to organizational effectiveness, particularly in Sanitary ware outlet where employees' interactions with customers have a strong effect on customers satisfaction. (Turban et al, 2006) believes that any organization seeks a competitive advantage in their industries in other word an advantage over competitors in some measure such as cost, quality, or speed. Cost leadership is one of Porter's two types of competitive advantage; the cost leader delivers a product of acceptable quality at the lowest possible cost. It attempts to open up a significant and sustainable cost gap over all other competitors. The cost advantage is achieved through superior position in relation to the key cost drivers. Cost leadership translates into profits if the cost leader can command the average prices in the industry. On the other hand, cost leaders must maintain quality that is close to, or equal to, that of the competition. (Lester, 1989) and the researchers at the MIT Industrial Performance Center identified seven areas of best practice were Simultaneous continuous improvement in cost, quality, service, and product innovation, Breaking down organizational barriers between departments, Eliminating layers of management creating flatter organizational hierarchies, Closer relationships with customers and suppliers, Intelligent use of new technology, Global focus, Improving human resource skills.

Globalization has been embraced in many countries put small business under more pressures, so it is timely and urgent for entrepreneur's small businesses to equip themselves with managerial and tactical competencies to remain competitive (Yaacob and Ju, 2013). Today, everything has changed due to globalization markets. E-commerce may help reach customers within an existing market who may not have visited vendors outlet, e-commerce is an innovative application of information technology by retail and global industries (Sunhilde, 2011). The modern way of business also changed, nowadays to achieve the low costs, the low prices, and attractive products, needed to be competitive, companies are thinking of international market instead of national (local) market. Demand for strong and superior competitive advantage has become a concern of every manager who is aware of the realities of the market. It is no longer enough to assume that good products will sell themselves, and that success today will be repeated in future (Porter M.E., 1980).From the consumers perspective, price is what the customer pays or gives for obtaining the product or service. Fairness of price is a psychological factor that plays an important role in the customers reaction to the paid price (Kim et al.,2006). Abdeldayem and Khanfar (2007) stated that the degree of disconfirmation felt by a consumer should diminish over time, it further identifies that consumers will learn as they gain experience with a product, and should adapt expectations consequently. Similarly (Getty and Thompson, 1994) in their study on lodging experience of customers found that customers only recommended the service provider to others, when they experienced a good quality service and when they were absolutely satisfied with the service offered with regards to the lodging experience. better management of the logistics chain means that customer service will become more efficient while lowering costs(Banabakova and Stoyanov, 2009). According to (Turban et al., 2006), porter's model has been used to develop strategies for companies to increase their competitive edge and it also demonstrates how IT can enhance the competitiveness of corporations. (Desouza believes 2001) that, Competitive intelligence can be done with technologies such as optical character recognition, intelligent agents and especially the Internet. The Internet is a company's most important tool to support competitive intelligence (Teo, 2000, Bell and Harari, 2000; Buchwitz, 2002). Power and Sharda (1997) proposed a framework in which the Internet capabilities are shown to provide information for strategic decisions. There are a lot of studies have examined consumers' switching habits using the traditional store and online channels. Demographics including age, household income, and faintly composition, had a significant effect on consumer perception of benefits for both online and store shopping (Dholakia et al., 2000). (Bhatnagar, 2006) believes the advances in IT have affected the lives of most of the human beings in their dayto-day lives. later, the type of business models might depend on how technology is used. Using technology, businesses can reach a large number of customers with minimal costs, A multi-channel retailer refers to the company who sells products through a traditional channel and the internet, Virtual channels can also extend the product scope and product 
depth of physical channels by enabling firms to offer new products that they do not have to physically stock locally (Sunhilde,2011). IT links a company with its business partners effectively and efficiently (Clemons and Hann, 1999). IT enables companies to reduce costs (Schwartz, 2000). IT creates innovative applications that provide direct strategic advantage to organizations (Bhise et al., 2000). Innovation is similar to differentiation except that the impact is much more dramatic. Differentiation "tweaks" existing products and services to offer the customer something special and different. Innovation implies something so new and different that it changes the nature of the industry (Turban et al, 2006). In Saudi Arabia we have many firms in sanitary ware industry, the fact of the matter is that, there is unorganized sector whereas rest is organized sector comprising of the sanitary ware industry in Makkah and Jeddah Cities are divided in two sectors. The organized sector majorly consisting of suppliers companies (M/s. SARA - Saudi Arabia Agencies Ltd, M/s. Traco Co, M/s. Al-Hayat Building Materials Co, M/s. Ebaa House Ceramic \& Marble Co, M/s. Saudi Marble \& Granite Factory Co, M/s. AISCO, M/s. Bani Thabyan Trading est...) who sale Sanitary ware (Bathroom Accessories, Mixers, and Bathtub) for the last 15-30 years and they have established their brand image. Generally unorganized sector's percentage of production capacity and also their sales in the local domestic Saudi Arabia market are higher than that of the organized sectors' sales. However, most literature has not clearly linked strategic management with Superior competitive advantage. Based on the above, the following hypothesis was drawn:

\section{H1. Strategic management has a significantly positive effect on Superior Competitive Advantage.}

More specifically:

(H1a): Environmental Scanning has a significantly positive effect on Superior Competitive Advantage.

(H1b): Strategy Formulation has a significantly positive effect on Superior Competitive Advantage.

(H1c): Strategy Implementation has a significantly positive effect on Superior Competitive Advantage.

$(\mathrm{H} 1 \mathrm{~d})$ : Evaluation and Control has a significantly positive effect on Superior Competitive Advantage.

$(\mathrm{H} 1 \mathrm{e})$ : Feedback / learning has a significantly positive effect on Superior Competitive Advantage.

\section{RESEARCH MODEL}

Based on study hypothesis, the following study model was proposed in order to show the relationships among independent and dependent variables. As can be seen from the framework, the study investigates the impact of Strategic Management (SM) on Superior Competitive Advantage (SCA), where Strategic Management (SM) is the independent variable positively related to Superior Competitive Advantage (SCA) as the dependent variable. This relationship was used to develop the hypotheses for this study. The model of the study is illustrated in below Figure (1.7)

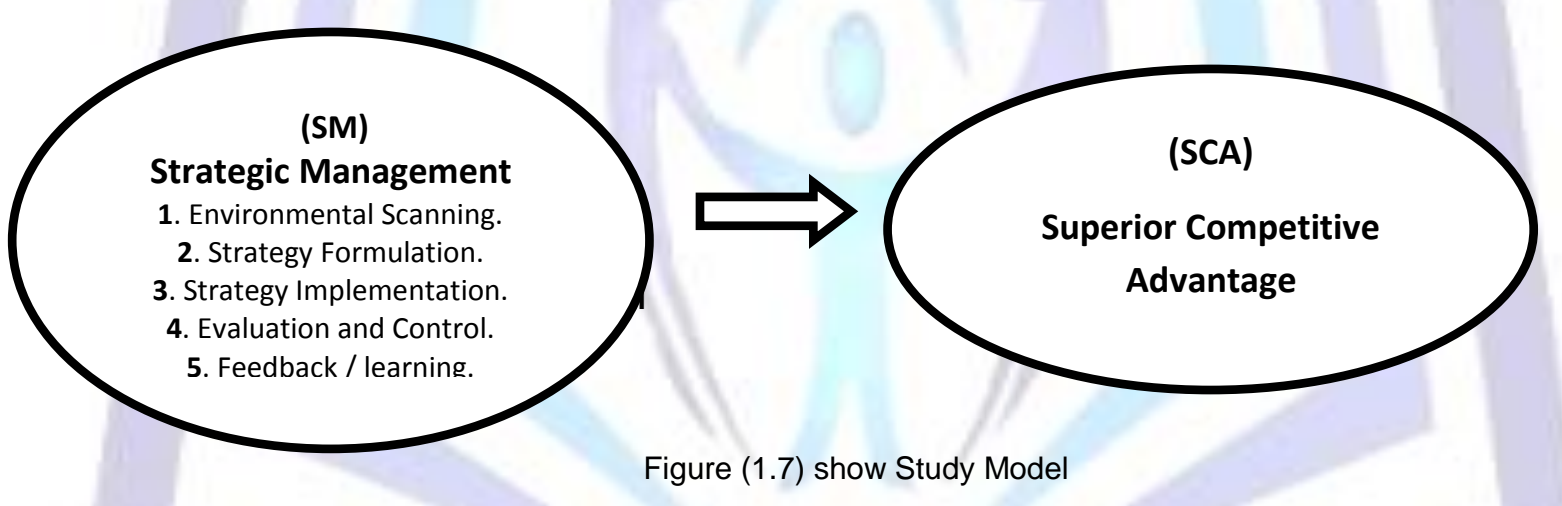

\section{METHODOLOGY}

In the present study, a survey was carried out on a sample of 112 retailers who purchase sanitary ware from Suppliers sanitary ware in Makkah and Jeddah Cities, Saudi Arabia. Retailer's sanitary wares were selected randomly and a sample was chosen by convenience sampling as the total population was unknown, both the primary and secondary methods of data collection were used. A structured questionnaire was administered among the customers to collect the response as primary data. The secondary source of data collection was through journals, books, magazines and through informal discussion with Retailers sanitary ware. The instrument used for data collection is a questionnaire titled "Strategy Management on Competitive advantage" developed by the researcher. The 22 -items questionnaire was based on a careful synthesis of Strategy Management on Competitive advantage, Age, Gender, Educational level, Experience and Functional level. The questionnaire was divided into three parts. Part one, two and three. Part one was designed to elicit personal information about respondents while part two and three focused and consisted of 22 items designed to elicit information on Strategy Management on Superior Competitive advantage on a five point Likert scale of Strongly Agree (SA), Agree (A); Mix feeling (MF); Disagrees (D) Strongly Disagree (SD) with points awarded in descending order of 5, 4, 3,2 , and 1.

\subsection{Study sample}

In order to minimize possible response bias, instructions emphasized that the study focused only on their personal opinions. There were no rights or wrong answers. After completion, the questionnaires were checked and collected by the researcher. However, due to some invalid questionnaires which were removed from the sample. The total sample size was 112, (Table I) shows the characteristics of the sample.

Table I. characteristics of the sample 


\begin{tabular}{|c|c|c|c|}
\hline General Information & Details & Frequency & \% Percent \\
\hline \multirow[t]{4}{*}{ Age group } & less than 30 & 50 & 44.6 \\
\hline & $30-$ less than 40 & 52 & 46.4 \\
\hline & $40-$ less than 50 & 9 & 8.0 \\
\hline & 50 years and more & 1 & 0.9 \\
\hline \multirow[t]{2}{*}{ Gender } & Male & 110 & 98.2 \\
\hline & Female & 2 & 1.8 \\
\hline \multirow[t]{5}{*}{ Educational level } & High school graduates or below & 14 & 12.5 \\
\hline & Diploma & 33 & 29.5 \\
\hline & Bachelor & 61 & 54.5 \\
\hline & Master & 4 & 3.6 \\
\hline & $\mathrm{PhD}$ & 0 & 0.0 \\
\hline \multirow[t]{4}{*}{ Experience } & less than 5 years & 29 & 25.9 \\
\hline & 5 - less than 10 & 45 & 40.2 \\
\hline & 10- less than 15 & 24 & 21.4 \\
\hline & 15 years and more & 14 & 12.5 \\
\hline \multirow[t]{3}{*}{ Functional level } & Low Management & 5 & 4.5 \\
\hline & Mid Management & 76 & 67.9 \\
\hline & High Management & 31 & 27.7 \\
\hline
\end{tabular}

In the preliminary analysis, age 50 (44.6 percent) belong to the less than 30 year-old category, 52 (46.4 percent) belonged to the 30 - less than 40 year old category, 9 (8.0 percent) belonged to the 40- less than 50 year old category, 1 (0.9 percent) belonged to the 50 year old \& more category. , with regard to 110 (98.2 percent) male were 2 (1.8 percent) female. In addition, 14 (12.5 percent) of the participants were high school graduates or below, 33 (29.5 percent) of the participants were diploma holders, whereas 61 (54.5 percent) were Bachelor degree, and 4 (3.6 percent) were Master degrees holders, 0 (0.0 percent) were PhD degrees holders. With regard to Experience, 29 (25.9 percent) belong to the less than 5 years experience, 45 (40.2 percent) belonged to the 5- less than 10 years experience, 24 (21.4 percent) belonged to the 10- less than 15 years experience, and 14 (12.5 percent) belonged to the 15 years and more years experience. Finally with regard to functional level 5 (4.5 percent) belonged to the Low Management, 76 (67.9 percent) belonged to the Mid Management, and 31 (27.7 percent) belonged to the High Management.

\subsection{Measure of the study}

All of our measures were created or adapted from scales that have been validated in prior research. The scales were customized wherever needed to make them relevant to the context of our study. All constructs were measured using fivepoint Likert scales with anchors strongly disagree $(=1)$ and strongly agree $(=5)$. All items were positively worded. Independent variable; Strategic Management (SM) measures by use 15-items questionnaire were designed and adopted by researchers to measure Strategic Management along five dimensions: environmental scanning, strategy formulation, strategy implementation, evaluation / control, and feedback / learning. In regards of dependent variables; Superior Competitive Advantage (SCA) measures were adapted from previous studies, 7 -items questionnaire were designed and adopted from (Wu and Lin, 2009; Porter,1985; Im and Workman 2004; Clemons and Hann, 1999; Schwartz, 2000; Sunhilde,2011).

\section{RELIABILITY AND VALIDITY OF THE SURVEY INSTRUMENT}

The survey instrument with 22 items was developed based on one variable as independent variables: Strategic Management (ES1 - FL3), and one dependent variable, Superior competitive advantage (SCA1-SCA7). The instrument was evaluated for reliability and validity. In order to achieve the reliability and validity of questionnaires forms which were used in this research, the questionnaire has been translated into Arabic language in additional of English version. The questionnaire for both language versions were discussed and compared to ensure that they were conceptually equivalent. 5.1 Psychometric properties and dimensions of Strategic Management (SM) scale and Superior competitive advantage

Kaiser-Meyer-Olkin and Bartlett's Test of Sphericity has been used as Pre-analysis testing for the suitability of the entire sample for factor analysis as recommended by Comrey (1978), the value of The Kaiser-Meyer-Olkinmeasure was used to assess the suitability of the sample for each unifactorial determination. The KMO values found (see Table II) are generally considered acceptable (Kim and Mueller, 1978).

Table II Kaiser-Meyer-Olkin and the Bartlett's Test of Sphericity

\begin{tabular}{|c|c|c|}
\hline & \multicolumn{2}{|c|}{ KMO and Bartlett's Test } \\
\hline \multirow{2}{*}{$\begin{array}{c}\text { Bartlett's Test of } \\
\text { Sphericity }\end{array}$} & Kaiser-Meyer-Olkin Measure of Sampling Adequacy. & 0.500 \\
\cline { 2 - 3 } & Approx. Chi-Square & 4.254 \\
\cline { 2 - 3 } & Df & 0.039 \\
\hline
\end{tabular}

All factors in each unifactorial test accounted for more than 42 percent of the variance of the respective variable sets. This suggests that only a small amount of the total variance for each group of variables is associated with causes other than the factor itself, and the Bartlet tests of sphericity was significant at $p<0: 01$, thus, indicating that the sample was suitable for factor 
analytic procedures (see Table V). It show that, KMO and Bartlett's Test shows Kaiser-Meyer-Olkin Measure of Sampling Adequacy $=0.500$, Approx. Chi-Square $=4.254, \mathrm{Df}=1$, the significant $0.039 \%<0.05 \%$ which mean all variables of study statistically significant. Component Matrix for dependent variable Superior Competitive Advantage (SCA) $=0.773 \mathrm{good}$, and for independent variables Strategic Management $(\mathrm{SM})=0.773 \mathrm{good}$.

\subsection{Factor Analysis}

Factor analysis was performed in order to reduce the diverse variables into a more meaningful number of variables and also assists in examining inter-relationships among the variables. Factor analysis and reliability analysis were used in order to determine the data reliability for the Strategic Management (SM) and Superior Competitive Advantage (SCA) measures factor analysis was performed to assess convergent validity. The results of the factor analysis and reliability tests are presented in below (Table III). On the basis of Cattel (1966) and Hair et al. (1998) criterion, factors with eigenvalues greater than 1.0 and factor loadings that are equal to or greater than 0.50 were retained. 22 items, loading under two factors, were extracted from the analysis. The two factors captured all of the variance with $\mathbf{4 0 . 2 4 0} \%$, and $59.760 \%$ of the variance respectively.

Table III Factor analysis of independent variable Strategic Management (SM) included (ES, SF, SI, EC, FL) and dependent variable Superior competitive advantage (SCA)

\begin{tabular}{|c|c|c|c|c|c|}
\hline & Variables & Loadings & Eigenvalue & Variance & Reliability \\
\hline SM & Strategic Management (independent) & 0.598 & 1.195 & 59.760 & 0.773 \\
\hline ES & Environmental Scanning & 0.868 & 1.264 & 25.272 & \\
\hline ES1 & $\begin{array}{l}\text { The supplier gathering information about sanitary } \\
\text { ware customers in regular basis }\end{array}$ & 0.773 & & & \\
\hline ES2 & $\begin{array}{l}\text { The supplier gathering information about sanitary } \\
\text { ware products and competitive brands in regular basis }\end{array}$ & 0.770 & & & \\
\hline ES3 & $\begin{array}{l}\text { The supplier prepares for the future by identifying new } \\
\text { trends and opportunities in the marketplace for } \\
\text { creating new sanitary ware product }\end{array}$ & 0.819 & & & \\
\hline SF & Strategy formulation & 0.673 & 1.099 & 21.989 & \\
\hline SF1 & $\begin{array}{l}\text { Supplier strategic plans of sanitary ware are } \\
\text { developing for long run. }\end{array}$ & 0.747 & & & \\
\hline SF2 & $\begin{array}{l}\text { Supplier mission emphasize his reason for existence } \\
\text { by providing sanitary ware regularly. }\end{array}$ & 0.736 & & & \\
\hline SF3 & $\begin{array}{l}\text { Supplier policies emphasize his selecting right } \\
\text { sanitary ware products with right price. }\end{array}$ & 0.745 & & & \\
\hline SI & Strategy implementation & 0.728 & 1.045 & 20.903 & \\
\hline Sl1 & $\begin{array}{l}\text { Supplier putting strategy of sanitary ware products } \\
\text { into action on right time. }\end{array}$ & 0.711 & & & \\
\hline SI2 & $\begin{array}{l}\text { Supplier strategy applies sequence of steps to do the } \\
\text { job of sanitary ware. }\end{array}$ & 0.718 & & & \\
\hline SI3 & $\begin{array}{l}\text { Supplier strategy Implementation of new sanitary } \\
\text { ware products is considered cost of the programs. }\end{array}$ & 0.778 & & & \\
\hline EC & Evaluation and Control & 0.626 & 0.858 & 17.163 & \\
\hline EC1 & $\begin{array}{l}\text { The supplier has improved its ability to innovate new } \\
\text { sanitary ware products. }\end{array}$ & 0.769 & & & \\
\hline EC2 & $\begin{array}{l}\text { The supplier has improved its ability to rapidly } \\
\text { commercialize new sanitary ware products. }\end{array}$ & 0.578 & & & \\
\hline EC3 & $\begin{array}{l}\text { The supplier has improved its ability to be responsive } \\
\text { to new sanitary ware market change. }\end{array}$ & 0.549 & & & \\
\hline FL & Feedback / Learning & 0.512 & 0.734 & 14.673 & \\
\hline FL1 & $\begin{array}{l}\text { Supplier focuses on creating differentiated sanitary } \\
\text { ware products and cost leadership. }\end{array}$ & 0.716 & & & \\
\hline FL2 & $\begin{array}{l}\text { Supplier resource commitment from senior } \\
\text { management is comparatively high in his firm. }\end{array}$ & 0.662 & & & \\
\hline \multirow[t]{2}{*}{ FL3 } & $\begin{array}{l}\text { Supplier uncertainty for return on investment (ROI) is } \\
\text { comparatively high in his firm. }\end{array}$ & 0.745 & & & \\
\hline & Variables & Loadings & Eigenvalue & Variance & Reliability \\
\hline SCA & $\begin{array}{l}\text { Superior Competitive Advantage } \\
\text { (dependent) }\end{array}$ & 0.598 & 0.805 & 40.240 & 0.773 \\
\hline SCA1 & $\begin{array}{l}\text { The supplier of sanitary ware is more likely to learn } \\
\text { from the experience of others competitors while his } \\
\text { resource is more limited and his performance is not } \\
\text { satisfactory. }\end{array}$ & 0.588 & & & \\
\hline SCA2 & $\begin{array}{l}\text { The supplier of sanitary ware delivers a product of } \\
\text { acceptable quality at the lowest possible cost that is }\end{array}$ & 0.709 & & & \\
\hline
\end{tabular}




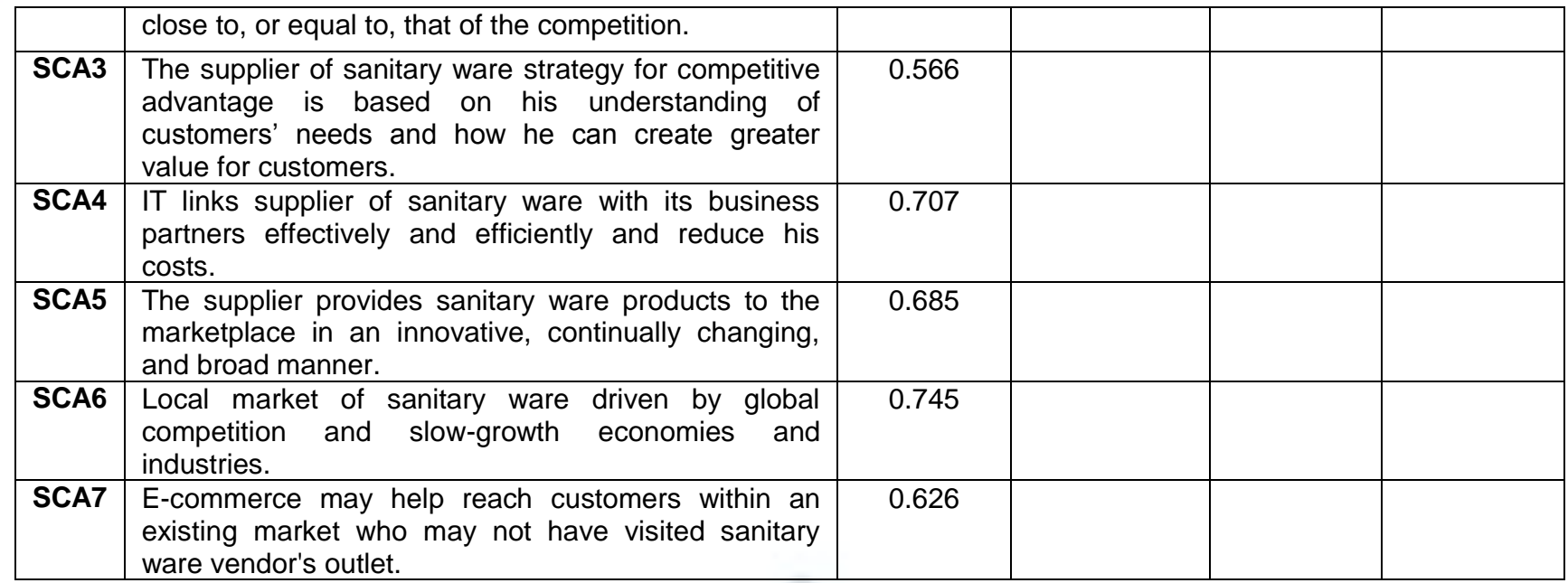

\subsection{Correlation analysis: relationships between the variables}

The correlation matrix in (Table IV) further indicates that Strategic Management (SM) was positively and moderately correlated with Superior Competitive Advantage (SCA). The correlation coefficients between the independent variables Strategic Management and the dependent variable Superior Competitive Advantage were less than 0.9, indicating that the data was not affected by a collinearity problem (Hair et al., 1998). These correlations are also further evidence of validity and reliability of measurement scales used in this research (Barclay et al., 1995; Hair et al., 1998). As can be seen in Table IV, the correlation coefficients for the variables under investigation were relatively ranging as 0.195 . Strategic management was highly correlated with superior competitive advantage $(r=0.195, p \leq 0.01)$. Strategic management (SM) had significant positive correlations ( $p, 0.01$ ) with Superior Competitive Advantage (SCA).

Table IV Summary of Means, standard deviations, and correlations of Strategic Management (SM) and Superior competitive advantage (SCA)

\begin{tabular}{|c|c|c|c|c|}
\hline Variables & Mean & S.D & SM & SCA \\
\hline \hline Strategic Management (SM) & 3.4196 & 0.30865 & 1.000 & 0.195 \\
\hline Superior competitive advantage (SCA) & 3.9758 & 0.38250 & 0.195 & 1.000 \\
\hline \multicolumn{2}{|l|}{ Notes: Correlation is significant at the 0.01 levels (two-tailed) }
\end{tabular}

\section{DESCRIPTIVE STATISTICS ANALYSIS}

Table V: Descriptive Statistics

\begin{tabular}{|c|c|c|c|}
\hline Variables (questions) & $\mathrm{N}$ & Mean & Std. Deviation \\
\hline ES1 & 112 & 3.1964 & 1.00305 \\
ES2 & 112 & 3.3125 & 0.81684 \\
ES3 & 112 & 3.1607 & 1.05313 \\
SF1 & $\mathbf{1 1 2}$ & $\mathbf{3 . 3 3 9 3}$ & $\mathbf{1 . 2 1 9 6 1}$ \\
SF2 & 112 & 3.4286 & 1.00193 \\
SF3 & 112 & 3.1339 & 1.11092 \\
SI1 & 112 & 3.5893 & 1.09506 \\
SI2 & 112 & 3.8482 & 0.90255 \\
SI3 & 112 & 3.6161 & 0.96091 \\
EC1 & 112 & 3.7500 & 1.05267 \\
EC2 & 112 & 3.1786 & 1.06724 \\
EC3 & 112 & 3.1250 & 1.03214 \\
FL1 & 112 & 3.3304 & 1.17319 \\
FL2 & 112 & 3.3482 & 0.95587 \\
FL3 & 112 & 3.9375 & 1.14121 \\
SCA1 & 112 & 3.5536 & 1.00305 \\
SCA2 & 112 & 4.3125 & 0.97751 \\
SCA3 & 112 & 3.8393 & 0.87563 \\
SCA4 & 112 & 3.9821 & 0.85931 \\
SCA5 & 112 & 4.1071 & 0.75166 \\
SCA6 & 112 & 3.9732 & 0.82155 \\
SCA7 & $\mathbf{1 1 2}$ & $\mathbf{4 . 0 6 2 5}$ & $\mathbf{0 . 7 3 8 6 5}$ \\
Valid N (listwise) & 112 & & \\
\hline
\end{tabular}


Above Descriptive Statistics (Table V), it is clear that the highest standard deviation was for question (SF1) Strategy formulation $=1.21961$ with Mean 3.3393 this indicate that the answers were less homogeneous, and the lowest standard deviation for question (SCA7) Superior competitive advantage $=0.73865$ with mean 4.0625

\section{MULTIPLE REGRESSION ANALYSIS}

Multiple regression analysis was employed to examine the impact of Strategic Management (SM) on Superior competitive advantage (SCA). It is a constructive statistical technique that can be used to analyze the association between a single dependent and several independent variables (Hair et al., 1998). Based on this method, the main independent variables (SM) and dependent variable (SCA) were entered together. The detail of the regression output was shown in Table (VI).

Table VI Regression results between Strategic Management (SM), and Superior Competitive Advantage (SCA)

\begin{tabular}{|c|c|c|c|c|c|c|}
\hline & \multirow{2}{*}{ Model } & \multicolumn{2}{|c|}{$\begin{array}{l}\text { Un-standardized } \\
\text { Coefficients }\end{array}$} & \multirow{2}{*}{$\begin{array}{c}\begin{array}{c}\text { Standardized } \\
\text { Coefficients }\end{array} \\
\text { Beta }\end{array}$} & \multirow[b]{2}{*}{$\mathbf{t}$} & \multirow[b]{2}{*}{ Sig. } \\
\hline & & B & Std. Error & & & \\
\hline \multirow[t]{6}{*}{1} & (Constant) & 2.631 & 0.408 & & 6.441 & 0.000 \\
\hline & ES & 0.130 & 0.060 & 0.191 & 2.156 & 0.033 \\
\hline & SF & 0.128 & 0.048 & 0.239 & 2.680 & 0.009 \\
\hline & SI & 0.133 & 0.055 & 0.217 & 2.439 & 0.016 \\
\hline & EC & 0.147 & 0.061 & 0.218 & 2.401 & 0.018 \\
\hline & $\mathrm{FL}$ & 0.101 & 0.051 & 0.178 & 1.986 & 0.050 \\
\hline
\end{tabular}

The regression model was statistically significant $(F=4.709 ; R 2=.0 .182 ; P=.000)$. The $R 2$ is 0.182 , which means that 18.2 per cent of the variation in Superior competitive advantage can be explained by Strategic Management. The proposed model was adequate as the F-statistic $=4.709$ were significant at the $5 \%$ level $(p<0.05)$. This indicates that the overall model was reasonable fit and there was a statistically significant association between Strategic Management (SM), and Superior Competitive Advantage (SCA). Regression analysis indicated that, Strategy Formulation had significantly positive effect on Superior Competitive Advantage $(p<0,05 ; ß=0.239)$. Thus, H1b, proposing that Strategy Formulation has a significantly positive effect on Superior Competitive Advantage, was supported by this study. The other result is Evaluation and Control had significantly positive effect on Superior Competitive Advantage $(p<0,05 ; ß=0,218)$. Hence the hypothesis $\mathrm{H} 1 \mathrm{~d}$ was also supported by the study.

Table VI: also shows that Strategy Implementation $(p<0,05 ; \beta=0.217)$, Environmental Scanning $(B=0.191, p<0.05)$, and Feedback / learning $(B=0.178, p<0.05)$, had a significant and positive effect on Superior Competitive Advantage. This provides evidence to support $\mathrm{H} 1 \mathrm{a}, \mathrm{H} 1 \mathrm{~b}, \mathrm{H} 1 \mathrm{c}, \mathrm{H} 1 \mathrm{~d}$, and $\mathrm{H} 1 \mathrm{e}$. Based on the values, Strategy Formulation has the highest impact on Superior Competitive Advantage followed by Evaluation and Control, Strategy Implementation, Environmental Scanning, and subsequently Feedback / learning.

\section{DISCUSSION}

The researcher believes that the current study has contributed to some extent in the developing understanding of Strategic Management the key for Superior Competitive advantage of Sanitary Ware (Bathroom accessories, Mixers, and Bathtub) Suppliers in Makkah and Jeddah Cities, Kingdom of Saudi Arabia. The real success of any organization or business lies in a Strategic Management (SM) and Superior Competitive advantage (SCA). This article is valuable in light of the general guidance of the relationship between Strategic Management and Superior Competitive advantage. In addition, this article contributes to redressing this imbalance by focusing on (SM) in detail. It provides insights into under-researched question of Does the Strategic Management the key for Superior Competitive advantage of Sanitary Ware (Bathroom accessories, Mixers, and Bathtub) Suppliers in Makkah and Jeddah Cities?

The most important finding is that if supplier does not apply Strategic Management, the application of business and Competitive advantage is almost of no significant impact. In case, a company does not take the time to think and implement Strategic Management correctly may turn out completely useless, increasing risk of error, costly mistakes, and misunderstanding market needed. From another side, the researcher finding is that, Suppliers can be achieving or bettering agreed organization goals through the development and implementation of Strategic Management. That strategy will reflect the organization's values, recognize its strengths and weaknesses compared to the competition, and have a view on the direction of the market in which it operates. One factor play big role in Saudi Arabia Market which is Product price. Sanitary ware product price elasticity is affected by substitute goods as more substitutes become available the 
demand becomes more elastic, since customer has more alternatives. Sanitary ware (Bathroom Accessories, Mixers, and Bathtub) products are perceived more costly in respect to its competitors. Therefore customer can divert to some less costly brand. Moreover there are many cheap Chinese Mixers products in market such as (Melody, Gold On, Tredex). From other side, If we compare Italian Mixers range that is imported range such as (Daniel, Fiore, Nobili, and Ottone Meloda) with other foreign brands, we found out that some foreign brands such as Germany brands (Grohe, Hansgrohe, and Hansa) are more popular than Italian mixer range as well as Spain brands such as (Roca and Maier), but that not mean no competitive advantage for Italian range, It mean Saudi Arabia Market fully with competitive sanitary ware brands with variety prices, quality and style (see Appendix 1.4). From another side, we found that, simple bathtub usually available in the market either made in Saudi Arabia or Bahrain, very a few brands international such as ROCA available in Makkah and Jeddah market due to high competition in prices usually local made cheaper than international made. In regards of bathtub with Jacuzzi we found that, there are many Chinese brands such as (Wisemaker, SSWW, Potter, Sannora, Ocean..etc) available widely in Jeddah market sanitary ware outlet with different sizes, specifications, style and price which give very good variety to customers to select what he need. In the same time very rarely to find bathtub with Jacuzzi made in Europe due to high price for the end and in Makkah and Jeddah market usually customer look for lowest prices with guarantee on product. Some of local sanitary ware supplier create his own brand name for bathtub Jacuzzi such as brand (Silver) which is own brand for M/s. Ebaa House Ceramic \& Marble Co. The study model is developed to imply various factors that are required to present more comprehensive set of factors that determine the overall sentiment of Superior Competitive advantage (SCA). The results of the main study have revealed that Suppliers of Sanitary ware did realise the benefits of Strategic Management(SM) connected their willingness toward Superior Competitive advantage (SCA) and use with some issues that have to be addressed previously in order to facilitate Superior Competitive advantage (SCA) in Makkah and Jeddah Cities. Not to mention with Strategic Management(SM)a faster pace of getting results, a higher business to success and reduced failure rate.

\section{LIMITATIONS AND RECOMMENDATIONS}

The study is only concerned towards 112 retailers who purchased from suppliers sanitary ware in Makkah and Jeddah Cities. It is assumed that respondents were honest in answering the questions while the survey was conducted. Moreover the study does not reflect the true picture of overall retailers from all the sanitary ware retailers either in Makkah and Jeddah cities or whole kingdom of Saudi Arabia.

This study is preliminary step to encourage researchers to undertake future studies, which shows the importance of Strategic Management as the key for Superior Competitive advantage of Sanitary Ware (Bathroom accessories, Mixers, and Bathtub) Suppliers in Makkah and Jeddah Cities, Kingdom of Saudi Arabia. The researcher encourages all supplier of sanitary ware to use Strategic Management and apply the dimensions (environmental scanning, strategy formulation, strategy implementation, evaluation / control and feedback / learning) to success sanitary ware business, reduce risk, avoid mistake, and improve business as overall. In addition, Strategic Management has a very important role to improve business relationship and satisfy both parties' suppliers and traders (retailers and wholesalers). The researcher's emphasis that, creating a strategic management map is a collaborative process, it typically starts out with CEO or Senior Executives who, from analysis of past performance and a view of the forecast business environment, will determine the goals to be achieved, the strategies to be employed, budget required and targets to guide execution. It is then the role of Operational Managers to develop action plans that implement each objective/strategy correctly that are deemed to be the best, affordable way to achieve them. Another thing to do to get people on board is to make sure our people understand enough of the basics of business that they can see how the strategy is going to make them better off, increase their job security, increase the likelihood that they get promotions, and how it will increase the likelihood that they see pay increases in the future. The researcher found that, successful strategic outcomes are best achieved when those responsible for execution are also part of the planning or formulation process. The researchers recommended that, $A$ Strategy coach should be someone who understands the business, the market in which it operates; who is a good communicator and can work well with operational managers. It is their responsibility to translate the strategy and work with operational managers to identify/validate the strategic initiatives required to achieve the objectives and superior competitive advantage. In the end the researcher recommend that, the suppliers should apply Strategic Management in their business and focus in understanding market needs, their like and dislikes as well as focusing on Strategic management to success business and reach to superior competitive advantage.

\section{REFERENCE}

[1] Abdeldayem, M. M. and Khanfar, M. R. (2007). "Consumer Expectation and Consumer Satisfaction Measurements: A Case Study from India”, The Business Review, Cambridge, Vol. 8 No. 2, pp. 303-309.

[2] Alnady, Baha'a (May.2012). "Effect of Customer Market Perceptions (CMP) and E- Loyalty on Business to Business Electronic Commerce (B2B EC) Success: An Empirical Study on Sample of E-retailers in Amman City", Thesis of Master degree in E-Business, Middle East University, Amman, Jordan.

[3] Banabakova, V. K., \& Stoyanov, M. S. (2009). Economic aspects of the relationship between logistics chain management \& competitive strategy. Buletin Stiintific, 14(2).

[4] Barney, J. B. (1991). Firm resources and Sustained competitive advantage. Journal of Management, 17: 1, 99-120.

[5] Bell, C. R., and O. Harari, (2000). Deep! Deep! Competing in the Age of the Road Runner, New York: Warner Books.

[6] Bhatnagar Ankit, (2006). Strategic Information Systems Planning: Alignment of 'IS/IT' Planning and Business Planning, Unitec New Zealand.

[7] Bagheri, Rouhollah et al. (2013). "Factors Affecting the Implementation of the Blue Ocean Strategy A Case Study of Medicom Production Manufacturing Company. University of Technology Tehran, Iran", Australian Journal of Basic and Applied Sciences, Vol. 7 No. 4, pp. 213-222, 2013. ISSN 1991-8178. 
[8] Barclay, D. W., Thompson, R. \& Higgins, C. (1995). "The partial least squares (PLS) approach to causal modeling: personal computer adoption and use an illustration”, Technology Studies, Vol. 2 No. 2, pp. 285-309.

[9] Bhise, H., et al. (2000). "The Duel for Doorstep", McKinsey Quarterly, Vol. 27 No. 2, pp.19-25.

[10] Bititci U., Martinez V., Albores P. and Mendibil K. (2003) 'Creating and Sustaining Competitive Advantage in Collaborative Systems: The What? And The How?' Production Planning and Control Journal (Forthcoming).

[11] Buchwitz, L. (2002). "Using the Internet for Competitive Intelligence", [Online] Available: members.attcanada.ca/ lillyb/Cl/page1.html, 2002.

[12] Cattel, R.B. (1966). "The scree test for the number of factors”, Multivariate Behavioral Research, Vol. 1 No. 2, pp.24576.

[13] Clemons, E. K., and I. H. Hann, (1999). "Rosenblatt International: Strategic Transformation”, Journal of MIS, Vol. 25 No. 1, Fall, pp. 10-30.

[14] Comrey AL.(1978). Common methodological problem in factor analytic studies. Journal of Consulting and Clinical psychology, 46, 648-659.

[15] Coyne, K. P. (1986). Sustainable Competitive Advantage: What it is and what it isn't. Business Horizons, January: $54-$ 61.

[16] Debi S. Saini, 2006. Book Reviews: Blue Ocean Strategy: How to Create Uncontested Market Space and Make Competition Irrelevant, VIKALPA, 31(3), JULY -SEPTEMBER 2006.

[17] DeGeus, A. (1988). Planning as learning. Harvard Business Review, Vol. 66 No. 2, pp. 70-74.

[18] Desouza, K. C. (2001). "Intelligent Agents for Competitive Intelligence: Survey of Application", Competitive Intelligence Review, Vol. 12, 4th quarter 2001, pp. 57-63.

[19] Dholakia,. R. R., \& Uusitalo, O. (2000). "Switching to electronic stores: Consumer characteristics and the perception of shopping benefits", Under Review at International Journal of Retail and Distribution Management.

[20] DeNisi, A.S. \&Kluger, A.N. (2000). "Feedback effectiveness: Can 360-degree appraisals be improved?" Academy of Management Executive, Vol. 14 No. 1, pp. 129-139.

[21] Ettlie, J.E., Penner-Hahn, J.D. (1994). "Flexibility ratios and manufacturing strategy", Management Science, Vol. 40 No. 11., pp. 1444-1454.

[22] Getty, J. M. and Thompson, K. N. (1994). "The Relationship Between Quality, Satisfaction, and Recommending Behavior in Lodging and Decision", Journal of Hospitality and Leisure Marketing, Vol. 2 No. 3, pp. 3-22.

[23] Goh, S.C. (2003). "Improving Organizational Learning Capability: Lessons Form Two Case Studies", The learning Organization, Vol. 10 No. 4, pp. 216-227.

[24] Grant, R. M. (1991). Contemporary Strategy Analysis: Concepts, Techniques and Applications. Cambridge: Black-well Publishers.

[25] Gregory, B.J., Levy, P.E. \& Jeffers, M. (2008). "Development of a model of the feedback process within executive coaching", Consulting Psychology Journal, Practice and Research, Vol. 60 No. 1, pp. 42-56.

[26] Grant, R. M. (2008). Contemporary Strategy Analysis, 6th edition, Blackwell Publishing, Oxford.

[27] Hair, J.F. Jr, Anderson, R.E., Tatham, R.L. and Black, W.C. (1998). Multivariate Data Analysis, 5th ed., Prentice-Hall International, Upper Saddle River, NJ.

[28] Hansen, M.T. (2002). "Knowledge networks: explaining effective knowledge sharing in multiunit companies", Organization Science, Vol. 13 No. 3, pp. 232-248.

[29] Harrison, M. (1990). Advanced Manufacturing Technology Management, Pitman Publishing, London.

[30] Henderson, B. (1983). The Anatomy of Competition. Journal of Marketing, 47: 7-11.

[31] Im, S., and Workman Jr., J. P. (2004). "Market Orientation, Creativity, and New Product Performance in HighTechnology Firms", Journal of Marketing Vol. 68 No. 2, pp. 114-132.

[32] Jarzebowski Ann-Marie et al. (March,2012). "When feedback is not enough: The impact of regulatory fit on motivation after positive feedback", International Coaching Psychology Review, Vol. 7 No. 1. The British Psychological Society ISSN: 1750-2764.

[33] Kim, W. G., Lee Y. K. and Yoo, Y. J. (2006). "Predictors of Relationship Quality and Relationship Outcomes in Luxury Restaurants", Journal of Hospitality and Tourism Research, Vol. 30 No. 2, pp. 143-169.

[34] Kim, Jae-On and Mueller, Charles W. (1978). Factor Analysis: Statistical Methods and Practical Issues, Sage, Beverly Hills, CA.

[35] Kirazci, Sadettin (2013). "Effects of verbal and visual feedback on anticipation timing", Middle East Technical University, Social Behavior and Personality, Vol. 41 No. 7, pp. $1133-1140$. http://dx.doi.org/10.2224/sbp.2013.41.7.1133.

[36] Koskiniemi, Anne and Perttula, Juha (2013). Team leader's experiences with receiving positive feedback, Lapland Rovaniemi University. ISSN 1392-3137. TILTAI, 1.

[37] Lester, Richard (1989). Made in America, MIT Commission on Industrial Productivity, Boston.

[38] Njuguna John I. (2009). Strategic positioning for sustainable competitive advantage: An organizational learning approach. Jomo Kenyatta University of Agriculture and Technology Juja, Kenya. KCA Journal of business management: Vol.2, Issue 1

[39] Nunnally, J.C. and Bernstein, I.H. (1994). Psychometric Theory, $3^{\text {rd }}$ edition, McGraw-Hill Inc., New York.

[40] Parthasarthy, R., Sethi, S.P. (1992). "The impact of flexible automation on business strategy and organizational structure", Academy of Management Review, Vol. 17 No. 1. pp. 86-111.

[41] Pearce, J.A. and Robinson, R. (2005). Strategy management: Formulation, implementation, and control, 9th edition, McGraw-Hill, New York.

[42] Peteraf, M. (1993). The cornerstones of competitive advantage: A resource-based view. Strategic Management Journal, 14: 179-191.

[43] Porter, M. (1980). Competitive Strategy: Techniques for Analyzing Industries and Competitors, Free Press, New York. 
[44] Porter, M. E., and V. E. Millar (1985). "How information gives you competitive advantage", Harvard Business Review, Vol. 63 No. 4, pp.149-158.

[45] Porter, M.E. (1996). "What is strategy?" Harvard Business Review, Vol. 74 No. 6, pp. 61-78.

[46] Power, B. S. and Sharda, R. (1997). "Obtaining Business Intelligence on the Internet", Long Range Planning, Vol. 42 No. 4, pp. 142-170.

[47] Prahalad, C. K., and Hamel, G. (1994). Competing for the future. Harvard Business Review, 72, 4: $122-128$.

[48] Pressman, Steven (1991), "The Competitive Advantage of Nations", by M. E. Porter, Journal of Management, Vol. 17.

[49] Rehman, S. U. \& Ibrahim, M. S. (2013), "A Study on Customer Satisfaction of Mobile Food Retailing in Salem City", CPS Journals, International Journal of Social Science Research, Vol. 1 Issue 1, pp: 49-58. ISSN: 2289-3318.

[50] Schwartz, E. (2000). Web Bots Enhance Self-Serve Experience. InfoWorld, February p. 7.

[51] Skinner, W. (1969). "Manufacturing-the missing link in corporate strategy", Harvard Business Review, Vol. 47 No. 3 , pp. $136-145$.

[52] Sunhilde Cuc (May.2011). Achieving Competitive Advantage through Using an Integrated Multi-selling Model. The Case from Romanian Linjerie Producer: Jolidon. University of Oradea, Romania. Journal of Electrical and Electronics Engineering, Volume 4, Number 1

[53] Sveiby, Karl-Erik (2001). "A knowledge-based theory of the firm to guide in strategy formulation", Swedish school of economics and business administration, Helsinki, Finland, Journal of Intellectual Capital, Vol. 2 No. 4, ABI/INFORM Global p.344.

[54] Swamidass, P.M., Newell, W.T. (1987). "Manufacturing strategy, environmental uncertainty and performance: a path analytic model", Management Science, Vol. 33 No. 4, pp. 9-524.

[55] Teo, T. S. H. (2000). Using the Internet for Competitive Intelligence in Singapore. Competitive Intelligence Review, Vol. 8 Issue 2, pp.16-23.

[56] Thenmozhi, S.P.\& Dhanapal, D.(2011),Unorganised Retailing in India-A study on Retail service Quality, European Journal of Social Service, 23(1): 68-75.

[57] Tracey Michael et al. (1999). "Manufacturing technology and strategy formulation: keys to enhancing competitiveness and improving performance", Purdue University, West Lafayette, Indiana 47907, USA, Journal of Operations Management, Vol. 17, pp. 411-428.

[58] Turban, E., Leidner, D., Mclean, E. and Wetherbe, J. 2006. 'Information Technology for Management: transforming organizations in the digital age'. 5th ed, John Willy \& Sons.

[59] Ward P.T., Leong, G.K., Boyer, K.K. (1994). "Manufacturing pro-activeness and Performance", Decision Sciences, Vol. 25 No. 3. pp. 337-358.

[60] Wheelen, Thomas L. et. al. (1981). "Strategic Management model, adapted from 'concepts of management", presented to society for advancement of management (SAM), International meeting, Richmond.

[61] Wheelen, Thomas L. \& Hunger, J. David (2006). Strategic Management and Business Policy, 10 $0^{\text {th }}$ ed., Pearson Education, Inc.

[62] Wu Ing-Long and Lin Han-Chang (2009). "A Strategy-Based Process for Implementing Knowledge Management: An Integrative View and Empirical Study", Journal of the American society for information science and technology, Vol. 60 No. 4, pp. 789-802.

[63] Yaacob, Mohd Rafi and Ju, Wong Poh (2013). "Strategic Practices in Hotel Industry in Langkawi Island, Malaysia Does Size Matter?" CPS Journals, International Journal of Social Science Research, Vol. 1 Issue 1, pp. 39-48. ISSN: 2289-3318.

[64] Yeung, A.K., Ulrich, D.O., Nason, S.W., von Glinow, M.A., 1999. Organizational Learning Capability. Oxford University Press, New York.

\section{Author's Biography}

Baha'a Abdul-Hafez Attallah Alnady is a holder of Master in E-Business, Faculty of Business, Middle East University, Amman- Jordan. He has 15 years of experiences as Business Coach and Senior in Management, Sales, Marketing, Procurement, Business development, Strategic Management, supply chain, benchmarking especially in the field of electric, electronic home appliances and Constructions building materials; he worked in many countries like; Jordan, Bahrain, Qatar, Italy and KSA. His research interest in Electronic commerce, Market strategies and Human behaviors appears in his Master thesis and research articles. Baha'a Al-Nady is the corresponding researcher and can be contacted at: bahadh@hotmail.com or GSM: 00966-540986039, GSM: +962-777729991, P.O. Box 230505 Amman 11123 Jordan.

Al-Hawary Sulieman I.SH. is an Associate professor of Business Management, at Faculty of Business and Finance, American University of Madaba, Jordan, he has been teaching in the Department of Business Administration for about 12 years. He received his PhD in Financial Management from the Rajasthan University, Jaipur, India. He possesses an M.Com from the University of Rajasthan, Jaipur, India, and a Bachelor in Commerce from the Yarmouk University in Jordan. His research interests are supply chain, TQM, service quality, brand, innovation, and HRM. Sulieman. I. Sh. AlHawary can be contacted at: dr_sliman73@aabu.edu.jo OR dr_sliman@yahoo.com.

Dr. Main Naser Alolayyan (Assistant Professor). A PhD holder at the Department of Quality and Productivity Improvement, University Kebangsaan Malaysia (UKM). Main obtained his M.Sc. From Yarmouk University in cooperation with the Royal College of Surgeon in Ireland (RCSI), in 2006, with concentration in the field of health service management. He obtained his bachelor degree in medical technology from Baghdad University in 2002. 


\section{Appendix}

Appendix 1: Description for Sanitary ware Categories (Bathroom accessories, Mixers, Bathtub) which available in Makkah and Jeddah cities, Saudi Arabia

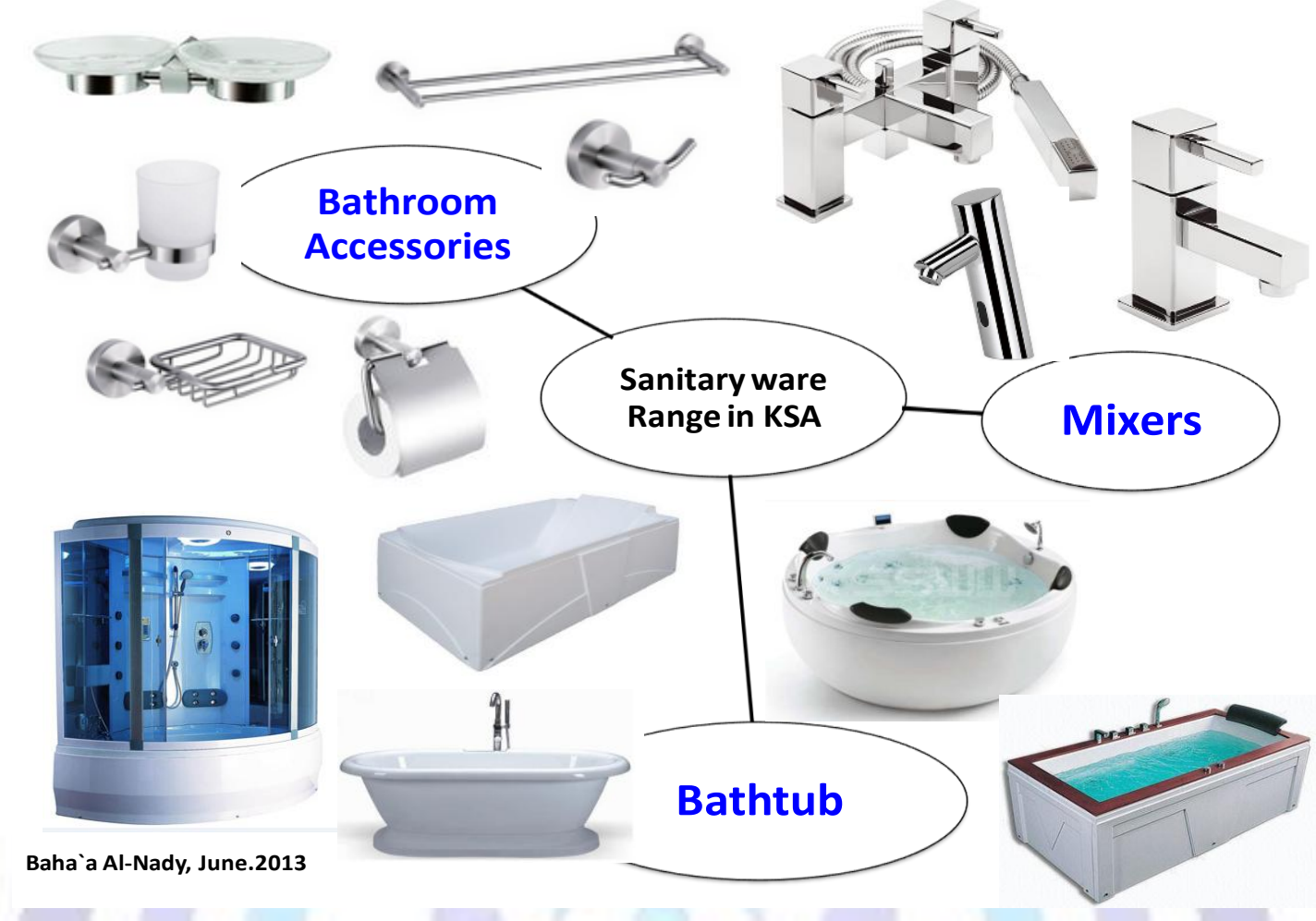

Appendix 2: Description for Sanitary ware international brands available in Makkah and Jeddah cities, Saudi Arabia

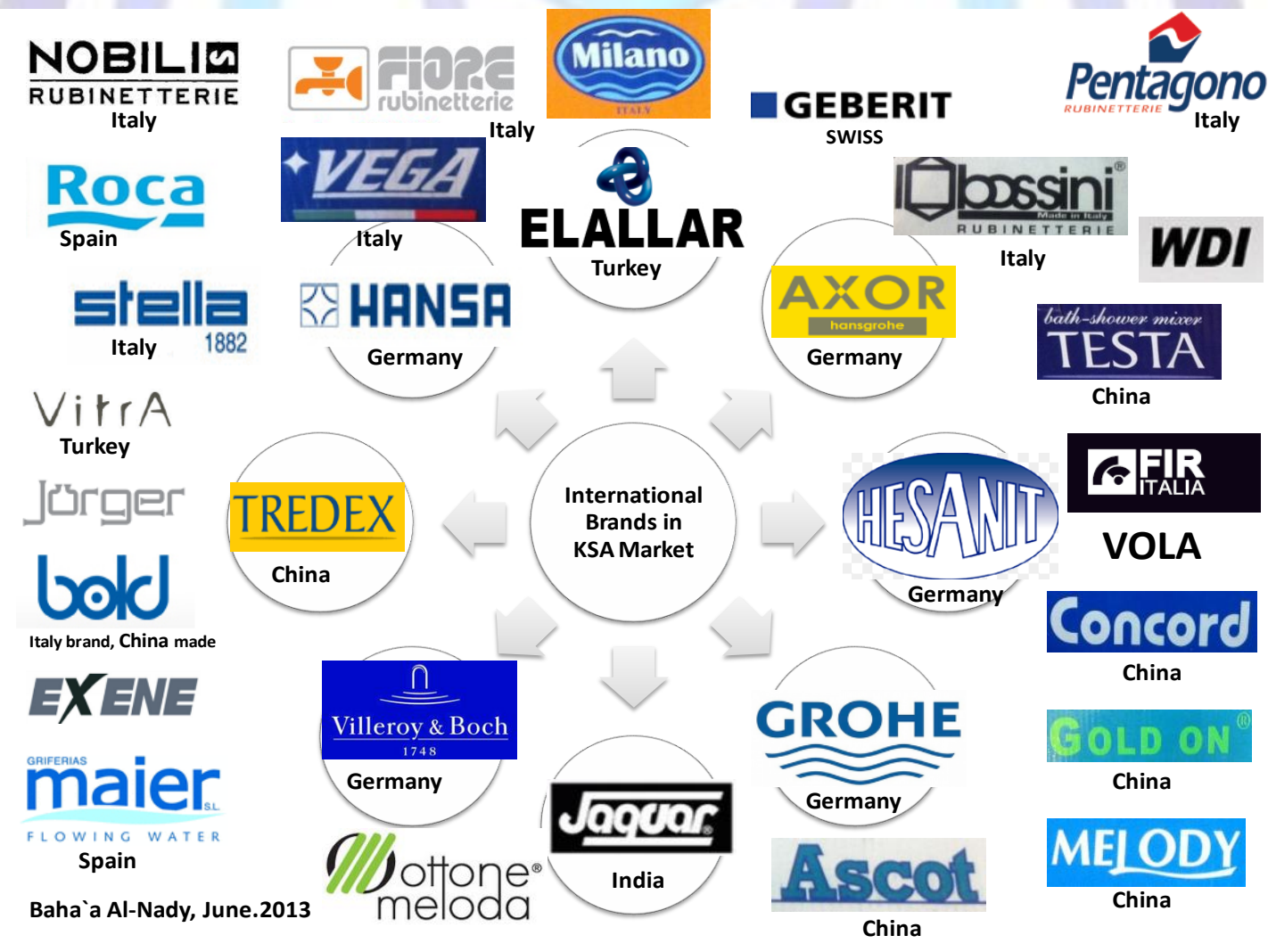

